assure him (or it), however, that the omission has been in no way connected with those "queer notions of honour, and justice, and fairness," which he conceives to be rife in our times. Why should I seek to wrong the honoured dead? And who would gain in this case by the injustice? The present Astronomer Royal? Surely no. To add this small matter to his real claims to our esteem would be

To gild refined gold, to paint the lily, And throw a perfume on the violet.

Neither, I am sure, has any other writer who has overlooked Flamstead's claims, desired to do him injustice. On this point I would merely remark, "Rest, rest, perturbed spirit."

But now "we'll shift our ground," by the Ghost's good leave.

Our visitor from Valhalla remarks that "a stir was lately made about what was represented as a new method of investigating the motion of the solar system in space, and instead of a new there was brought forward an old acquaintance (known to Science since the times of our grandfathers)." Here the spirit of Flamstead refers obviousiy to the Astronomer Royal's method. I am sure that Prof. Airy would desire greatly that if his method be indeed so ancient, the fact should be made widely known. I myself am particularly anxious to be set right on this point, about which $I$ am at this very time writing. For though I care more about explaining this and the other methods than about their history, yet it is desirable to be accurate even in historical details.

If I may say so without offence, I would remark that a ghost was not needed-certainly not the ghost of the first Astronomer Royal--to teach astronomers that the opposition of Mars in 1877 will be exceptionally important. At page 25 of my "Sun "I have already pointed this out, and I dare say others have done likewise.

I hope the "great injustice" to which our ghostly correspondent refers as endured by him in life, does not relate to his difficulties with Newton, for at the present time the opinion of Brewster on this point is in vogue--not Baily's ; and the warmest a dmirers of Flamstead are those who least desire to moot the subject.

Brighton, Nov, 4

\section{Creators of Science}

PERMIT me to do my little towards clearing up a most unfortunate confusion of thought respecting the intellectual ranks of mathematicians and metaphysicians, which is, in my experience, widely prevalent. We may safely divide the mathematicians into three orders :- (I) Inventors, (2) Experts, (3) Readers or Students, so as to discriminate from one another those who create systems, those who manipulate with them, as "ministers and interpreters of nature"-just as easily and familiarly as Professor Tait $(e, g$. employs and applies the theory of Quaternions-and those who have merely studied into an understanding of an author or subject. It was an expedient of the late Sir William Stirling Hamilton to confound all these orders, and from the heterogeneous lump to extract-if not extort-testimonies to the worthlessness of mathematics as a mental discipline, without the least discrimination of their sources.

On the other hand, the metaphysicians cannot be trichotomised; for, even in the present advanced state of metaphysics, there is no class of philosophers corresponding to the mathematical experts, the reason of which explains why examiners in mental science do not set problems. There are, in fact, only two classes of metaphysicians : I., Creators ; II., Students, more or less thoroughly verseu in the systems of the leaders, and more or less accepting or rejecting, with more or less reason, those creations. Accordingly, when on May I7, 1869 (I think that was the date), Professor Tait, at a meeting of the Royal Society of Edinburgh, challenged the metaphysical world to produce a metaphysician who was also a mathematician, he not being able at the moment to call to mind a single instance, he was to be understood as asking for a person of the order I, who was also in the class I. Professor Calderwood's reply, then, was not wholly unexceptionable, for of the three names he adduced, viz., Descartes, Leibnitz, and Hegel, the last was that of a reader of mathematics, and not of a mathematical inventor. The challenger might have spared the respondent the trouble of reply, had he known what De Morgan wrote in Notes and Queries, 2nd S. vi. 293-4, where are distinguished five mathematical inventors, as facile principes: viz., Archimedes, Galileo, Descartes, Leibnitz, and Newton ; and in which Aristotle, Plato, and D'Alembert are allowed a very high rank in mathematics. Had the inventor of Quaternions been then dead, I have little doubt that De Morgan would have added to the five the name of Sir William Rowan Hamilton, who, besides being a mathematical inventor of the very first rank, was also a diligent and accomplished student of Plato, Kant, Reid, and the other Hamilton, and a writer on Logic ; $i, e_{\text {, as good as }}$ D'Alembert as a philosopher, and perhaps better than he as a mathematician. Now, it is not a little curious and very instructive to observe that, pace Platonis, the two who were creators of strictly defined metaphysical systems, viz., Descartes and Leibnitz, are the only two among the five metaphysicians adduced by $D e$ Morgan who belong to the highest rank as mathematical inventors.

It is quite incredible that a man of Professor Tait's learning (I say here nothing of his judgment) should not have been aware of the identity of Descartes (the poor dreamer!) and Cartes, the founder of the Cartesian Geometry; still more so that he should not have known that the immortal analyst, the co-inventor of the Differential Calculus, was the most eminent metaphysician native to Germany before Kant. It was, then, not "ignorance," but "ignoration," on the part of the Scotch mathematician, that was involved in his challenge ; and that challenge was doubtless intended as mere badinage, at the expense of a science which he had taken no pains to understand.

Be that as it may, I trust I am not singular in adjudging (as De Morgan did) these two grand intellectual pursuits to be worthy of being cultivated together, and to be able to give material aid to each other. For myself, I cannot but look upon any man as the enemy of intellectual progress, who delights in setting the one class of investigators against the other, and endeavours to prolong the controversy which has raged between them since the "Principia" was promulgated.

Highgate, Nov. 8

C. M. Ingleby

\section{Descartes" "Animated Machines"}

As you open your valuable columns to philosophieal discussions, may I request you to publish the following remarks on a passase in Mr. Lewes's popular. "History of Philosophy" (Vol.ii.p. I 48 of the new edition), where he confesses himself puzzled, along with other critics, to account for Descartes' theory that animals were only animated machines. "I am not prepared," he says, "with a satisfactory explanation." I cannot but think that a careful perusal of the "Discourse on Method" (Part 5, sub. fin.) and of the treatise on les Passions de l'âme, makes Descartes' reasons perfectly clear. In the first place, the use of the word machine has misled most of his critics, and if the story of Malebranche and his dog be true, even this great disciple had grievously mistaken the principles of his master. For in the last-named treatise Descartes endeavours to show that such feelings as joy, grief, fear, \&c., though in us accompanied by really mental acts (pensées), are produced by physical causes, and produce physical effects apart from the mind. Descartes would therefore never have denied to brutes any of the bodily sensibilities which we possess ; and says expressly that he calls them machines in a special sense-machines made by the Deity, and therefore infinitely more subtle and perfect than any which we can construct. He says that we could not ourselves be ranked higher in the scale of beings did we not possess the gift of language, the phenomena of which can only be accounted for by an internal principle different in kind from those which appear to guide the lower animals, though there are also those passions in us which we have in common with them.

But to come to the psychological reasons for the theory. His torians of philosophy before the 18 th century should be particularly alive to theological idola, even in sceptical writers; much more so in good Catholics like Descartes. Just as Berkeley put forward prominently the theological advantages of his Idealism so Descartes indicates plainly in his "Discourse on Method" (loc. cit.) that these were the chief reasons of his theory. "Next to the error of those who deny the Deity, which I have already refuted, there is none more apt to seduce feeble minds from the path of virtue than to imagine that the soul of beasts is the same as ours." But the locus classicus has, I think, escaped Mr. Lewis, and will be found in a letter to a Lord (supposed to be the Duke of Newcastle), the 54th of the Ist volume in the original quarto edition. Descartes there specially answers objections made to him on this point, and in the way above indicated; adding however the following passage: "Yet it may be said that although the beasts perform no action which convinces us that they think, never* theless, as the organs of their bodies do not differ much from ours, it may be conjectured that some sort of thought is joined to these organs, such as we exprerience in ourselves, but much less perfect ; 